\title{
Taming the Beast? New European Regulation for Credit Rating Agencies
}

\author{
by Jakob de Haan and Fabian Amtenbrink
}

This paper discusses the proposal of the European Commission for further regulation of Credit Rating Agencies (CRAs), focusing on what the proposal will imply for: (1) the large concentration in the market for credit ratings, (2) the overreliance of investors and regulators on credit ratings, (3) the conflicts of interest that arise due to the business model of CRAs, (4) the lack of transparency and liability, and (5) the role of CRAs in rating sovereign debt. It is concluded that the political agreement on this proposal as a result of the trilogue between the European Parliament (EP), the Council of the European Union and the European Commission can hardly be considered breaking ground on any of the major issues identified in this contribution.

Der Beitrag untersucht einen Gesetzentwurf der Europäischen Kommission zur weitergehenden Regulierung von Ratingagenturen, unter besonderer Beachtung der Auswirkungen des Vorschlags auf (1) die geringe Anbieterzahl auf dem Rating-Markt, (2) die übermäßige Abhängigkeit von Investoren und Regulierungsbehörden von Ratingagenturen, (3) die Interessenkonflikte, die bislang aus dem Geschäftsmodell von Ratingagenturen erwachsen, (4) den Mangel an Transparenz und Haftbarkeit sowie (5) die Rolle von Ratingagenturen bei der Bewertung von Staatsschuld. Es erweist sich, dass der aus dem Trilog von Europäischem Parlament (EP), Rat und Europäischer Kommission entstandene politische Beschluss über den vorliegenden Entwurf mit Blick auf die benannten umfassenderen Fragen kaum bahnbrechende Neuerungen enthält.

\section{Introduction}

Further European integration is needed in several areas. For instance, when it comes to restrictions on national fiscal policies of Member States of the euro area, delegation of national sovereignty in favour of European cooperation is needed. ${ }^{1}$ Recently, some potentially promising steps have been taken in this regard. However, sometimes the way European integration progresses may be questioned, even if there are good reasons for policies that go beyond the na-

1 Cf. de Haan, J./Gilbert, N./Hessel, J./Verkaart, S.: Beyond the Fiscal Compact: How Well-Designed Eurobonds May Discipline Governments, in: ZSE 10/3 (2012), 323-337. 
tional level. An example concerns the regulation of credit rating agencies (CRAs) in the European Union (EU). CRAs play an important role in financial markets through the production of credit risk information and its distribution to market participants. CRAs essentially provide two services. First, they offer an independent assessment of the ability of issuers to meet their debt obligations, thereby providing "information services" that reduce information costs, increase the pool of potential borrowers, and promote liquid markets. Second, they offer "monitoring services" through which they influence issuers to take corrective actions to avert downgrades via "watch" procedures. ${ }^{2}$ However, CRAs have been identified as one important actor in the emergence as well as the unfolding of the recent financial crisis. ${ }^{3}$ Since, they have also been charged with having at least contributed to the unfolding of the euro area debt crisis through their approach to sovereign debt rating. It is thus not surprising that the regulatory environment in which CRAs operate has come under review on both sides of the Atlantic and has also been considered a priority area for regulatory recommendations by the G-20 which already at its 2009 London Summit pledged "to extend regulatory oversight and registration to Credit Rating Agencies to ensure they meet the international code of good practice, particularly to prevent unacceptable conflicts of interest."

The European Union followed-up on this commitment by the adoption in 2009 of Regulation 1060/2009 on Credit Rating Agencies (CRA 1) which entered into full application on 7 December 2010 and for the first time set out rules of conduct for CRAs in the EU. ${ }^{5}$ The introduction of the regulatory framework for CRAs preceded the much broader EU financial market regulatory and supervisory reform. In fact, the creation of the European system of financial supervisors and namely the establishment of the European Securities and Markets Authority (ESMA) required an amendment of the just established CRA regulatory frame-

2 For an analysis, cf. Amtenbrink, F./De Haan, J.: Credit Rating Agencies, in: Eijffinger, S./Masciandaro, D. (eds.): Handbook of Central Banking, Financial Regulation and Supervision, Cheltenham, 573-615. Also recently Gildehaus, H.: The rating agency oligopoly and its consequences for European competition law, in: European Law Review, 37/3 (2012), 269-293.

3 See, for example, the De Larosière Report (2009): The High-Level Group on Financial Supervision in the EU chaired by Jaques de Larosière, Report (Brussels, 25 February 2009).

4 London Summit - Leaders' Statement of 2 April 2009.

5 Regulation 1060/2009 of the European Parliament and of the Council on Credit Rating Agencies, OJ 2009 L 302/1. For an appraisal see Amtenbrink, F./De Haan, J.: Regulating Credit Ratings in the European Union: A Critical First Assessment of Regulation 1060/2009 on Credit Rating Agencies, in: Common Market Law Review, 46 (2009), 1915-1949. 
work. ${ }^{6}$ Accordingly the CRA Regulation was amended in May 2011 (CRA 2) recognising the new role of ESMA having exclusive supervisory powers over CRAs registered in the EU in an attempt to centralise and simplify their supervision at the European level. ${ }^{7}$

Only six months later, in November 2011, the European Commission published yet another proposal to further amend the European regulatory framework for CRAs. ${ }^{8}$ In the opinion of the European Commission, "a number of issues related to credit rating activities and the use of ratings have not been sufficiently addressed in the existing CRA Regulation." "Indeed, it could be observed that the original Regulation 1060/2009 had not effectively addressed some major issues pertaining to the way in which CRAs operate and that have contributed to CRAs being criticised for their role in the financial crisis. This concerns notably: (1) the large concentration in the market for credit ratings, (2) the overreliance of investors and regulators on credit ratings, (3) the conflicts of interest that arise due to the business model of CRAs, (4) the lack of transparency and liability, and (5) the role of CRAs in rating sovereign debt.

This contribution offers a legal and economic analysis of these issues against the backdrop of the European Commission proposal and the political agreement on this proposal from the trilogue between the European Parliament (EP), the Council of the European Union and the European Commission. ${ }^{10}$ The main question to be answered is whether the proposed amendments of the existing EU regulatory framework on CRAs will remove or at least alleviate these issues. For this purpose the proposal is analysed based on the above-mentioned problem areas.

6 Regulation 1095/2010 of the European Parliament and of the Council establishing a European Supervisory Authority (European Securities and Markets Authority), amending Decision 716/2009/EC and repealing Commission Decision 2009/77/EC, OJ 2010 L 331/84.

7 Regulation 513/2011 of the European Parliament and of the Council of 11 May 2011 amending Regulation 1060/2009 on credit rating agencies, OJ 2011 L 145/30.

8 European Commission: Proposal for a Regulation of the European Parliament and of the Council amending Regulation (EC) No 1060/2009 on credit rating agencies, COM (2011) 747 final. The proposal is accompanied by an Impact Assessment study (SEC (2011) 1354) (hereafter referred to as 'the Impact study'.

9 Ibid., 2.

10 Proposal for a Regulation of the European Parliament and of the Council amending regulation (EC) 1060/2009 on credit rating agencies - political agreement, Brussels, 3 December 2012, 16680/12 (hereafter: the proposal). 


\section{Concentration in the rating market}

Although there are quite a few CRAs, the market is dominated by three major CRAs (Fitch, Moody's and Standard \& Poors), with a combined market share above 95 per cent globally. ${ }^{11}$ Moody's Investor Services is owned by Moody's Corporation that is listed on the New York Stock Exchange. Standard \& Poor's is owned by the American publisher McGraw-Hill, which is also listed on the New York Stock Exchange. Fitch, which is the smallest of the big three with a market share of 15 per cent globally, is a subsidiary of the French financial company Fimalac that is listed on Euronext Paris.

Competition is hampered by the existence of strong economies of scope and of scale and by the importance of reputation in the market for credit ratings. According to the European Commission Impact Study, the absence of a standardised rating scale is another factor hindering competition. ${ }^{12}$ The oligopolistic nature of the rating market has led to calls for more competition and entry of new rating firms. ${ }^{13}$ For instance, in June 2011 the EP issued a report in which it called for more competition and expressed support for the creation of networks of smaller CRAs. Yet scant academic research sounds a clear warning about the impact of more competition on the quality of the ratings. Becker and Milbourn have examined how the quality of ratings issued by Standard \& Poor's and Moody's, responded to the new competition presented by Fitch. ${ }^{14}$ These authors find that the ratings issued by Standard \& Poor's and Moody's rose as competition increased, while the ratings have become less informative about the value of bonds when raters face more competition. These findings suggest that measures to enhance entry of new competitors should deal with the incentive of CRAs to keep a business relationship with firms they rate even if that implies lower quality ratings. From this perspective, the proposed rotation rule discussed hereafter in this section should be welcomed.

The EP also considered that the establishment of an independent European Credit Rating Agency should be explored and assessed by the European Commission. The Proposal does not as such introduce a European Credit Rating

11 Impact Study, 4.

12 Ibid., 18.

13 Generally on the application of the EU competition rules to CRAs see the analysis by Gildehaus, H., op. cit., 2012.

14 Becker, B./Milbourn, T.: How Did Increased Competition Affect Credit Ratings?, 2010. Available at: http://www.hbs.edu/research/pdf/09-051.pdf. 
Agency however. The Impact Study rightly observed in this regard that even if a publicly funded CRA would increase the diversity of opinions in the rating market, it would be difficult to address concerns relating to conflicts of interest and its credibility, especially if such CRA would rate sovereign debt. In the latter regard, the proposal does however include a reference to the possibility of the establishment of a European Credit Rating Agency. As part of an amendment of its reporting requirements laid down in Article 39 Regulation 1060/2009, the European Commission in the future is also supposed to report "on the appropriateness and on the possibility to support a European credit rating agency dedicated to assessing the creditworthiness of Member States' sovereign debt and/or a European Credit Rating Foundation for all other ratings." " establishment of such European bodies has thus not been entirely shut.

In the current proposal, the suggestion that the ECB should be in charge of rating sovereign debt is also rejected. This is to be welcomed. The Impact Study identifies three major arguments against the attribution of this task to the ECB. First, there may be a conflict of interest between the activity of issuing sovereign debt ratings and the implementation of its monetary policy notably with respect to rules concerning collateral. Second, there would be a serious reputational risk. Third, as the ECB is an independent institution with concrete tasks notably in terms of monetary policy, issuing sovereign ratings would require institutional considerations, including, possibly, a modification of the EU Treaty. ${ }^{16}$

Rather than - for the time being - to create a quasi-public CRA to create more competition, the European Commission is exploring ways to use EU funds to promote the creation of networks of smaller CRAs so to allow them to pool resources and generate efficiencies of scale. ${ }^{17}$ The proposal foresees that by the end of 2013 the European Commission puts forward a report that "shall evaluate financial and non-financial support for the creation of such a network, taking into consideration the potential conflict of interests arising from such public funding." 18

Moreover, several measures in the Proposal aim to contribute to more diversity and choice in the credit rating industry by attempting to break open the system whereby a single CRA on a contractual basis permanently issues ratings for the

17 Explanatory Memorandum to the European Commission Proposal, 11.

18 Art. 39aa(3). 
same issuer. Article $6 \mathrm{~b}$ of the Proposal foresees a rotation system by introducing a maximum duration of the contractual relationship with a CRA. Different to the original Commission proposal, which in broad terms referred to "the issuing of credit ratings"19, the current proposal refers specifically only to "the issuing of credit ratings on re-securitisations", whereby in the case of the existence of such a contract the CRA is not permitted to issue ratings on new re-securitisations with underlying assets from the same originator for a period exceeding four years. ${ }^{20}$ A new contract may not be entered in for the issuing of credit ratings on re-securitisations with underlying assets from the same originator in principle for the period of the expired contract. The proposal foresees in an exemption from the maximum duration of the contractual relationship if at least four CRAs each rate more than 10 per cent of the total number of outstanding rated resecuritisations from the same originator. ${ }^{21}$ With these arrangements one gets the impression that the original Commission proposal has been somewhat toned down as the restrictions only apply to re-securitisations with underlying assets from the same originator, excluding already issued ratings, and the three year contract period originally foreseen has been extended by a year. Moreover, the requirement foreseen in the original proposal whereby for solicited ratings the CRA engaged should not be in place for more than a year if it rates more than ten consecutive rated debt instruments of the issuer has been removed. ${ }^{22}$ Also the originally foreseen requirement for a CRA that has reached the end of the allowed contractual period to provide the incoming CRA with a handover file including relevant information has not been included in the current proposal for re-securitisation. ${ }^{23}$ The Preamble to the proposal offers some insights into the motives behind this substantive amendment of the rotation system as foreseen in the original proposal. Namely reference is made to the potential negative consequences of such a rotation system for issuers and credit rating agencies because the cost associated with rating a new entity or instrument is typically higher than the cost of monitoring an already issued rating, the time and resources involved in getting established as a CRA and a possible "significant impact on the quality

19 Art. 6b(1) Proposal for a Regulation by the European Parliament and of the Council amending Regulation No 1060/2009 on credit rating agencies, $\operatorname{COM}(2011) 747$ final (hereafter: original proposal).

20 Art. $6 b(1)$.

21 Art. $6 b(3)$.

22 Art. 6b (1)-(2) original proposal.

23 Preamble No. 7a states in this regard in rather vague terms that the introduction of such a requirement should be evaluated if a rotation system was also introduced for other asset classes. 
and continuity of ratings. ${ }^{24}$ It is also stated that "although there is currently only a limited number of credit rating agencies active in the market for rating resecuritisations, this market is more naturally open to competition and a rotation mechanism could be a driver for creating more dynamics in this market that is "dominated by a few large credit rating agencies but there are other players who have been building expertise in this area." 25 Finally, it is emphasised that the CRA market needs to be able "to gradually adapt before possibly enhancing the mechanism in the future". When considering these arguments one cannot help but get the impression that in its currently proposed shape the rotation system is really envisaged as a trial or experiment rather than a well-thought through system. While re-securitisation with its high risks involved is undoubtedly an important asset class to include in CRA regulation, the potential loss of impartiality and lock-in effects as a result of long-lasting business relationships with the same CRA equally apply to other asset classes. The arguments put forward for a limitation of the rotation system to re-securitisation are not entirely convincing.

Although to a more limited extent than foreseen in the original proposal, the proposed restraints will result in a larger number of CRAs being involved in the rating of credit ratings on new re-securitisations and may thus result in new entrants in the market for credit ratings at least to some extent. The question is how such newcomers will be perceived by the financial markets given that it can be expected that, at least initially, they cannot match the credibility of the big global players. One may wonder whether the increased diversity of CRAs will also result in more diversity in credit ratings or rather more of the same. Even if the requirement of a handover file has not made the current proposal the question arises whether the new, possibly much smaller CRAs will feel compelled to follow the assessments of their potentially larger competitor that is considered more credible by financial markets. ${ }^{26}$ What is more, it is notable that the rotation rule does not apply to unsolicited ratings on re-securitisation from the same originator. ${ }^{27}$ While it may be argued that it is the very nature of unsolicited ratings that in principle any CRA may provide ratings on a particular instrument, this argument may not be very convincing when applied to sovereign ratings, which in most instances are produced as unsolicited ratings. Here the enormous

24 Preamble No. 7a.

25 Preamble No. $7 \mathrm{~b}$.

26 The idea behind the handover file as stated in the original proposal was to 'to ensure the comparability with the ratings carried out by the existing credit rating agency.'

27 As expressly stated in Preamble No. 11. 
head start in terms of credibility means that the largest CRAs can still consolidate their dominant position. ${ }^{28}$ Whether the breaking open of long-term business relationships through the obligation to rotate reduces the familiarity threat to the independent assessment of credit risk by CRAs while the business relationship lasts is also questionable. ${ }^{29}$ What can be said is that in the future such conflicts of interest would not last forever and could be drawn in the open as a result of a (much) less favourable rating by another CRA.

In the original proposal the intention of the European Commission to deal with the threat to competition that may result from market consolidation was clearly expressed as it was observed that "consolidation in the credit rating market driven by large established players would result in a reduction of the number of available registered credit rating agencies, thus creating selection difficulties for issuers at the moment in which they regularly need to appoint one or more new credit rating agencies and disturbing the smooth functioning of the new rules. More importantly, further consolidation driven by large established credit rating agencies would particularly prevent the emergence of more diversity in the market." 30 Offering a somewhat different perspective the European Commission Impact Study stated that "The ban for large CRAs from acquiring small and medium-sized CRAs would be necessary to ensure effectiveness of other preferred options, including those addressing issues on CRAs' independence. However, this ban on its own would not be effective to change the market structure and could be circumvented by CRAs." 31 Yet, while the explanatory memorandum to the original proposal referred to "the proposed prohibition for large credit rating agencies to acquire other CRAs over a period of ten years" ${ }^{32}$, no corresponding provision could be found in the actual original draft Regulation. In the current proposal the reference to market concentration has been removed altogether. ${ }^{33}$ Under the heading "Conflicts of interest concerning investments in credit rating agencies" Article 6a of the current proposal prohibits shareholders or members of a CRA holding at least 5 per cent of the capital or the voting rights in that agency inter alia to hold 5 per cent or more of the capital of any other CRA to have a right or the power to exercise 5 per cent or more of the

28 With regard to sovereign ratings, see also section VI.

29 With regard to conflicts of interest, see also section IV.

30 Preamble No. 17 original proposal.

31 Impact Study, at 45.

32 Explanatory Memorandum to the original proposal, 11.

33 In fact a preamble No. 17 is missing altogether in the version of the proposal of 3 December 2012. 
voting rights in any other CRA, or to otherwise have the power to exercise, or actually exercise, dominant influence or control over any other CRA. Investments in other CRAs belonging to the same group of CRAs are excluded from this prohibition.

The proposal also aims to make comparison of ratings somewhat easier by introducing a so-called European Rating Platform that provides all available ratings per instrument to be run by ESMA with the aim to "allow investors to easily compare all ratings that exist with regard to a specific rated entity" and "to consider the whole variety of opinions before taking their investment decisions." ${ }^{34}$ Article 8a requires issuers to disclose specific information on structured finance products on an ongoing basis through a centralised website operated by ESMA. Under the proposed Article 11a, CRAs are moreover required to forward to ESMA rating information and in particular "the rating and outlook of the rated instrument, information on the type of rating, the type of rating action, and date and hour of publication." This information is thereafter published on a website. ${ }^{35}$ Similar to what has been observed for the rotation system, there are some notable differences between the original Commission proposal and the political agreement about this proposal. Firstly, the idea of the establishment of common standards for rating scales and a European Rating Index (EURIX) has been abolished. Originally it was foreseen that ESMA would be empowered to develop draft technical standards, for endorsement by the European Commission, on a harmonised rating scale to be used by CRAs, whereby all ratings would have had to follow the same scale standards. Finally, CRAs will be required to annually disclose to ESMA a list of fees charged to each client, for individual ratings and any ancillary service, and to disclose to ESMA their pricing policy, including pricing criteria in relation to ratings for different asset classes. ${ }^{36}$ While in principle the idea of a European Rating Platform has to be welcomed as it can enhance transparency and with it competition as the performance of CRAs becomes somewhat more comparable, the lack of a harmonised rating scale means that it is not excluded that investors will actually end up comparing apples with pares.

Also some other proposed amendments arguably aim at providing more competition in the rating market. Article $8 \mathrm{~b}$ requires issuers who solicit a rating to en-

34 Preamble No. 23.

35 See also Art. 8a that requires issuers to disclose specific information on structured finance products on an ongoing basis through a centralised website operated by ESMA.

36 Annex I, Section E, Part II, point 2. 
gage two credit rating agencies to issue two independent credit ratings in parallel on the same structured finance instruments. Interestingly, Article $8 \mathrm{ba}$ aims at stimulating issuers to mandate one of the smaller CRAs, as they are supposed to "consider the possibility to mandate at least one credit rating agency which does not have more than 10 per cent of the total market share and which can be evaluated by the issuer as capable for rating the relevant issuance or entity, provided that there is a credit rating agency available for rating the specific issuance or entity". For this purpose ESMA is supposed to annually publish on its website a list of EU-registered CRAs "indicating their total market share and the types of ratings issued".

\section{Overreliance on credit ratings}

The overreliance on credit ratings by financial market participants is a welldocumented criticism of today's financial market system. In fact, as counterintuitive as it may sound, regulation of CRAs as currently in place may actually deteriorate the situation. It has been observed by the authors of this contribution that "comprehensive regulation may actually result in more reliance on the ratings of structured financial instruments by investors that are given the false impression that the ratings of EU registered CRAs are more reliable [...] Put differently, the (amended) Regulation implies that CRAs have to adhere to various requirements, creating the impression that their ratings can be trusted. Also the fact that ESMA and not an independent institution monitors rating performance may add to this impression.,"37

Concerns about overreliance on credit ratings are widely shared. For instance, in October 2010 the Financial Stability Board (FSB) endorsed principles to reduce authorities' and financial institutions' reliance on ratings. ${ }^{38}$ These principles were also endorsed by the G-20. Overreliance on ratings may lead to herd behaviour and cliff effects. Herd behaviour occurs if investors refrain from making an investment when they learn that others have decided not to do so or when they make an investment when they learn that others do so. Cliff effects may be described as sudden actions that are triggered by a rating downgrade under a specific threshold, where downgrading a single security can have a disproportionate

37 Amtenbrink, F./De Haan, J., op.cit., 609-610.

38 FSB, principles for reducing reliance on CRA ratings, adopted on 27 October 2010. Available from: http://www.financialstabilityboard.org/publications/r_101027.pdf. 
cascading effect. ${ }^{39}$ For instance, a downgrade may lead to a sell-off of the downgraded instrument, which may cause a downward price spiral if investors only base their decisions on ratings. Overreliance on credit ratings has been stimulated by references to credit ratings in financial regulation. That is why the proposal for a revised Capital Requirements Directive (CRD IV), adopted by the Commission on 20 July 2011, provides banks with an incentive to use internal rather than external credit ratings for the purposes of calculating regulatory capital. ${ }^{40}$

Article 5a of the Proposal requires that financial entities, including credit institutions, investment firms, insurance and reassurance undertakings, institutions for occupational retirement provisions, management and investment companies and alternative investment fund managers, make their own credit risk assessment. They should therefore avoid relying "solely or mechanistically" on external credit ratings for assessing the creditworthiness of assets. ${ }^{41}$ Competent authorities should supervise the adequacy of these financial firms' credit assessment processes including monitoring that financial firms do not over-rely on credit ratings. According to the European Commission's Impact Study "internal ratings can prove beneficial for the macro- financial stability only if internal rating methodologies are carefully and accurately reviewed and approved by a competent authority. The need to validate internal rating methodologies would clearly create an additional burden for CRAs supervisors." ${ }^{42}$ Whether, and if, to what extent, financial institutions will be able to come up with realistic risk assessments that are considered as credible as those by CRAs need to be seen. In any event the question is whether by foreseeing a central role for supervisory authorities in ensuring the adequacy of these internal assessments these authorities are not being effectively put in the somewhat awkward position of at least indirectly evaluating credit risks themselves. This may not go well with their role as an independent supervisor of CRAs.

The proposal also explicitly addresses overreliance on external credit ratings by Union law and Union institutions and bodies. Article 5ba of the proposal sets the ambitious aim to "eliminate all references to ratings in Union law by 1st of January 2020, provided that appropriate alternatives to credit risk assessment have

39 Impact Study, 8. See also Amtenbrink, F./Heine, K.: Regulating Credit Rating Agencies in the European Union: Lessons from Behavioural Science, Dovenschmidt Quarterly, forthcoming.

40 COM (2011) 453 final and COM (2011) 452 final.

41 Art. 5a of the Proposal.

42 Impact Study, 26. 
been identified and implemented." Under the proposed new Article 5b, ESMA and the other European Supervisory Authorities, such as the European Banking Authority (EBA) and the European Insurance and Occupational Pensions Authority (EIOPA), should not refer to credit ratings in their guidelines, recommendations and draft technical standards where such references have the potential to trigger mechanistic reliance on credit ratings by competent authorities or financial market participants. Moreover, they are called upon to adapt their existing guidelines and recommendations accordingly, and by 31 December 2013 at the latest.

The issue of overreliance on ratings by financial institutions is also dealt with in another recent European Commission proposal for a Directive on the access to the activity of credit institutions and the prudential supervision of credit institutions and investment firms. ${ }^{43}$ There the European Commission proposes the introduction of a rule requiring banks and investment firms to assess themselves the credit risk of entities and financial instruments in which they invest and not to simply rely on external ratings in this respect. Finally, the European Commission has proposed amendments to the regulatory framework applicable to undertakings for collective investment in transferable securities (UCITS) and Alternative Investment Fund Managers to ensure that the principle of avoiding overreliance on credit ratings is also integrated into the national legislation implementing those directives. ${ }^{44}$

The Proposal does not change the responsibilities of ESMA with respect to monitoring the reliability of ratings. ESMA is responsible for hosting a central repository in which CRAs will become obliged to make available information on their historical performance data including the ratings transition frequency and

43 Commission proposal of 20 July 2011 for a Directive of the European Parliament and of the Council on the access to the activity of credit institutions and the prudential supervision of credit institutions and investment firms and amending Directive 2002/87/EC of the European Parliament and of the Council on the supplementary supervision of credit institutions, insurance undertakings and investment firms in a financial conglomerate, COM (2011) 453 final.

44 Directive 2009/65/EC of the European Parliament and of the Council on coordination of laws, regulations and administrative provisions relating to undertakings for collective investment in transferable securities (UCITS), OJ 2009 L 302/32; Directive 2011/61 of the European Parliament and of the Council on Alternative Investment Fund Managers and amending Directives 2003/41/EC and 2009/65/EC and Regulations 1060/2009 and 1095/2010, OJ 2011 L 174/1; Commission proposal of 15 November 2011 for a Directive of the European Parliament and of the Council amending Directive 2009/65/EC on the coordination of laws, regulations and administrative provisions relating to undertakings of collective investment in transferable securities (UCITS) and Directive 2011/61/EU on Alternative Investment Funds Managers in respect of the excessive reliance on credit ratings, COM (2011) 746 final. 
information about credit ratings issued in the past and on their changes. ${ }^{45}$ ESMA must make that information publically available and must publish summary information on the main developments observed on an annual basis. This is not to say, however, that ESMA will undertake and publish an analysis of that performance or indeed compare the performance of different CRAs. This in spite of the advice of the Issing Committee that the "rating performance (i.e. the longterm statistics relating initial ratings to subsequent defaults) should be monitored by the regulators, applying high statistical standards. Rating performance relative to outcomes should be published regularly (e.g., once a year). ${ }^{, 46}$ In this context, Goodhart has argued in favour of an independent institution, a CRA Assessment Centre (CRAC), whose only task would be to assess the accuracy of CRA estimates and to publish comparative studies of such accuracy. All CRAs in all countries should be required to place with CRAC a record of each product rated and a measure of the uncertainty of this rating. This might help competition. Goodhart argues that "A new entrant could establish a track record for greater accuracy (again independently assessed) in a particular niche by exploiting a comparative advantage, say in rating one particular product line, with a small staff and build from that. What investors want is forecast accuracy. At present they have no simple or straightforward way of checking that $[\ldots]$ So most investors fall back on reliance on brand names, which reinforces oligopoly." 47

From the perspective of addressing overreliance on credit ratings the added value of the requirement to mandate at least two CRAs to rate a structured finance instrument described in the previous section is questionable. Indeed, it is hard to see how asking for more ratings will reduce the overreliance on credit ratings. What is more, the European Commission's own Impact Study for the original proposal has identified drawbacks, observing that "the potential benefits of this individual option on reducing overreliance are likely to be limited since the ratings issued by different CRAs, with regard to one issuer or instrument, tend to be similar." 48 Of course the same argument may also apply to the proposed new

45 Art. 11(2).

46 Issing Committee, New Financial Order: Recommendations by the Issing Committee, Frankfurt: Center for Financial Studies, 2008. Available at: http://www.ifkcfs.de/fileadmin/downloads/publications/white_ paper/White_Paper_No_1_Final.pdf, 10.

47 Brackets added. Goodhart, C.A.E.: How, if at all, should Credit Ratings Agencies (CRAs) be Regulated?, in: LSE Financial Markets Group Paper Series, Special Papers 181, 2008, 31-32.

48 Impact Study, 28. 
obligation to limit the contractual relationship with any one CRA and to oblige issuers to change CRAs.

\section{Conflicts of interest}

The issuer-pays model is by far the dominant remuneration model in the rating market. This model entails conflicts of interest as CRAs have a financial interest in generating business from the issuers that seek the rating, which could lead to assigning higher ratings than warranted in order to increase its revenues from the issuer. If reputational concerns or regulation are not strong enough to discipline CRAs, the issuer-pays model can result in inflated ratings. As pointed out above, more competition may in fact increase this risk. So it would therefore seem crucial that measures are taken to redress this issue.

The European Commission has argued that unsolicited ratings are not constrained by the issuer-pays model and are therefore less affected by potential conflicts of interests. ${ }^{49}$ This may be questionable at least in the context of sovereign ratings. In fact there have been instances reported in which a CRA threatened to withdraw an unsolicited sovereign rating if the rated entity would not pay for this rating. As it is important for sovereigns to be rated, it is likely that they will pay in the end. It is quite remarkable that this practice is not discussed in any of the documents submitted by the European Commission.

CRAs have an incentive to seek long-lasting relationships with the issuer which may raise "the threat of familiarity, as the credit rating agency may become too sympathetic to the desires of the rated entity [...] Issuers are also subject to incentives that favour long-lasting relationships, such as the lock-in effect: an issuer may refrain from changing credit rating agency as this may raise concerns of investors regarding the issuer's creditworthiness." ${ }^{\text {"No }}$ The Proposal does not change the business model of the CRAs fundamentally, but comes up with amendments aiming to redress some of the risks of this model. Alternative payment models are the "investor-pays", "trading venues-pay", and the "public utility" model. It is quite remarkable that the latter option is hardly discussed in the European Commission's Impact Study that identifies several drawbacks of the investor-pays and the trading venues-pay models. Investors may have their own interests, so ratings paid by investors would not be free of potential conflicts 
of interest. Furthermore, as investors seek to be compensated for increased rating costs they are likely to require higher returns on investments, so that the cost of funding for issuers will increase. In addition, investors' reliance on ratings could further increase. Finally, the investor-pays model could make it difficult for smaller issuers of less liquid issuances to find a CRA willing to rate them and, consequently, to raise funds at the capital markets. ${ }^{51}$ The Impact Study moreover also questions the effectiveness of the trading venues-pay model, as it would only cover securities that are traded on trading venues but not those which are traded over-the-counter. Yet, currently, a large proportion of securities are traded over-the-counter. Furthermore, it would be difficult to find criteria that trading venues could use in order to attribute rating mandates to credit rating agencies. Finally, it has been argued that this model will force trading venues to change their business model and make use of experts capable of selecting appropriate CRAs. This would involve additional costs to be born by the clients which could make public listing more expensive. ${ }^{52}$

The before mentioned proposed rotation system will end the current practice of long-lasting relationships between CRAs and issuers, albeit only for new resecuritisations with underlying assets from the same originator. The hope is that this will "effectively address the lock-in effect, where an issuer refrains from changing credit rating agency as this would raise concerns of investors regarding the issuer's creditworthiness. ${ }^{, 53}$ Mandatory rotation of CRAs is also believed to create more opportunities for smaller CRAs to compete by producing a track record of quality ratings. According to the Proposal, "Multiple and different views, perspectives and methodologies applied by credit rating agencies should produce more diverse credit ratings and ultimately improve the assessment of the creditworthiness of the re-securitisations. ${ }^{54}$

Yet, whether the latter will indeed be the case crucially depends on whether the ratings of the CRAs frequently differ, are independent from each other, and are regarded as equivalents. In fact several authors have investigated these issues. Hill et al. have analysed differences in sovereign rating levels across CRAs employing sovereign ratings data for 129 countries spanning the period 1990- 
$2006{ }^{55}$ The study concludes that more often than not CRAs disagree about the rating of a sovereign obligor. However, disagreement tends to be within one or two notches on the finer scale. It has also been noted that financial markets may react differently to rating changes made by different CRAs. For instance, Brooks et al. report an unequal reaction to sovereign rating changes across agencies. Whereas Standard \& Poor's and Fitch induce a significant market reaction only when they downgrade a sovereign rating, only upgrade announcements by Moody's are associated with a positive abnormal return. ${ }^{56}$ Moreover, there is evidence for a certain degree of interaction between CRAs. Alsakka and ap Gwilym investigate the presence of lead-lag relationships among sovereign ratings assigned by five CRAs, namely Moody's, Standard \& Poor's, Fitch, Japan Credit Rating Agency, and Japan Rating \& Investment Information. ${ }^{57}$ They find that Moody's seems to be the first mover in upgrading sovereign issuers, but Standard \& Poor's tends to lead Moody's rating downgrades. The Japanese agencies are influenced by the rating dynamics of Standard \& Poor's and Fitch, but not vice versa. Kiff et al. report that Moody's tends to lag behind Fitch's and Standard \& Poor's. Moody's and Fitch tend to follow Standard \& Poor's negative rating actions more often than Standard \& Poor's follows the others. ${ }^{58}$ Considering these findings, serious doubts can be raised as to whether more ratings will indeed mean more diverse ratings and an opportunity for small CRAs to distinguish themselves sufficiently.

The Proposal comes up with some other measures to enhance CRAs' independence. For instance, under Annex I, Section B, point 3a of the Proposal, the fees charged by CRAs to their clients should be non-discriminatory and not be based on any form of contingency, thus for example not depend on the result or outcome of the work performed. This new provision aims at avoiding that rated entities could pay higher fees in exchange of overly favourable ratings.

Another conflict of interest may come from the ownership structure of CRAs. As has been observed in section 2, according to the Proposal, investors holding a

55 Hill, P./Brooks, R./Faff, R.: Variations in sovereign credit quality assessments across rating agencies, in: Journal of Banking and Finance, 34 (2010), 1327-1343.

56 Brooks, R./Faff, D./Hillier, J.: The national market impact of sovereign rating changes, in: Journal of Banking and Finance, 28 (2004), 233-250.

57 Alsakka, R./ap Gwilym, O.: Leads and lags in sovereign credit ratings, in: Journal of Banking and Finance, 34 (2010), 2614-2626.

58 Kiff, J./Nowak, S., Schumacher, L.: Are Rating Agencies Powerful? An Investigation into the Impact and Accuracy of Sovereign Ratings, IMF Working Paper, 12/23, 2012. 
participation in a CRA face restrictions in holding participation in any other CRA. This restriction is necessary to guarantee the perception of independence of CRAs, which could be affected should the same shareholders significant invest significantly in different CRAs, even if those shareholders are not in position to legally exercise dominant influence or control.

Finally, it is proposed that a lead analysts should not be involved in rating the same entity for more than 4 years regardless of on behalf of which CRA the analyst rates the entity. ${ }^{59}$ Also the compensation and performance evaluation or rating analysts and persons approving credit ratings or rating outlooks may not depend on the amount of revenue that a CRA derives from the rated entity. ${ }^{60}$

\section{Civil liability and transparency}

According to the European Commission's Impact Study, the possibility of sanctioning CRAs if they do not adhere to the CRA Regulation is not a substitute for an efficient right of redress for investors and does not compensate investors for their losses. ${ }^{61}$ Yet, in the existing EU CRA regulatory framework there has been a notable absence of any rules on the civil liability of CRAs. Currently, an investor suffering a loss due to a breach of the CRA Regulation faces considerable hurdles, to say the least, when wanting to claim for compensation for a faulty rating. Contractual liability is excluded since in the currently used business model it is the issuer rather than the investor who has a contractual relationship with the CRA. Thus, as Blaurock has noted, the issue is one of "rating agencies [incurring] civil liability if third parties were consciously intended to suffer damage through the issuance of an incorrect rating grade. However, this will very rarely be the case. Rather, the question of the agencies' liability for a negligently too positive evaluation of the issuer or its product, for a delay in issuing a downgrade, or for negligently caused procedural and publication errors, attains significance. $" ~{ }^{2}$

The Proposal foresees in a provision dealing with the extra-contractual liability of CRAs. According to the Article 35a of the Proposal CRA will be rendered liable in case of infringements, intentionally or with gross negligence, referred to

59 Annex I, section C, point 8.

60 Art. 7(5).

61 Impact Study, 46.

62 Blaurock, U.: Control and Responsibility of Credit Rating Agencies, in: Electronic Journal of Comparative Law 11/3 (2007), 22, brackets added. 
in a new Annex III of the CRA Regulation, thereby causing damage to an investor having relied on a credit rating of such CRA, provided the infringement in question affected the credit rating. For this investors must establish that they have relied, in accordance with Article 5a or otherwise with due care, on that rating for a decision to invest into, hold onto or divest from a financial instrument covered by that rating." For issuers of financial instruments the proposal demands that it must be established "that it or its financial instruments are covered by that rating and the infringement was not caused by misleading and inaccurate information provided by the issuer to the credit rating agency, directly or through information publicly available." The proposal does not define the terms damage, intention, gross negligence, reasonable reliance, due care and impact, but states that they "shall be interpreted and applied in accordance with the applicable national law as determined by the relevant rules of International Private Law." ${ }^{, 63}$ Different to the current proposal, the original proposal had offered at least some indication as to what amounts to gross negligence stating that for this it is required that a CRA "seriously neglects duties imposed upon it" ${ }^{64}$

Doubts can be raised as to the effectiveness of this proposed civil liability framework. ${ }^{65}$ First of all, while arguably reflecting the current state of European integration of civil law, the reference to the domestic legal frameworks does mean that there will be at least some diversity in the liability of EU registered CRAs for infringements of the CRA regulation. ${ }^{66}$ What is more, already the explanatory memorandum to the original proposal had recognised that "As investors do not have close insight in internal procedures of credit rating agencies a partial reversal of the burden of proof with regard to the existence of an infringement and the infringement's impact on the rating outcome seems to be appropriate if the investor has made a reasonable case in favour of the existence of such an infringement. However, the burden of proof as regards the existence of a damage and the causality of the infringement for the damage, both being closer to the sphere of the investor, should fully be on the investor', the Regulation itself does explicitly foresee in such a partial reversal of the burden of proof,

63 Art. $35 \mathrm{a}(5 \mathrm{a})$.

64 Art. 35a(3) of the original proposal.

65 See however Gildehaus (op.cit.) who argues that 'If those amendments are really implemented as proposed, they will constitute another important step forward in making CRAs more accountable.'

66 It has to be noted in this context that also the original proposal had not been entirely clear on what exactly would have constituted a 'serious neglect', as the explanatory memorandum to the original proposal at p. 21 only stated that 'that credit rating agencies should not face liability claims if they neglect individual obligations under the Regulation without disregarding their duties in a serious way.' 
as it states that it is the responsibility of the claimant "to put forward accurate and detailed elements indicating that the credit rating agency has committed an infringement of this Regulation, and that that infringement had an impact on the credit rating issued." The proposal leaves it to the competent national court to determine what qualifies as an accurate and detailed element and restricts itself to stating that in deciding on this issue it should be taken into account that "the investor or issuer may not have access to information, which is purely within the sphere of the credit rating agency." ${ }^{, 67}$ It is notable that the current proposal does not include any reference to the role of the CRA in this context, whereas the original proposal stated that once the claimant has established "facts from which it may be inferred that a credit rating agency has committed any of the infringements" it is for the CRA "to prove that it has not committed that infringement or that that infringement did not have an impact on the issued credit rating." Indeed, how exactly an investor is supposed to bring a reasonable case that a CRA has seriously neglected the highly detailed and complex duties imposed upon it by Regulation 1060/2009 and, moreover, the causality of such neglects for the damage he has incurred remains a real concern. ${ }^{68}$ What is more, while in the original proposal a contractual exclusion of limitation of civil liability was explicitly ruled out ${ }^{69}$, the current proposal explicitly allows for a limitation of civil liability if the liability is reasonable and proportionate, as well as allowed by the relevant national law. ${ }^{70}$

The proposal also foresees several measures to improve transparency. Articles $8(5 a)$ and $8(6)$ and lay down procedures for the preparation of new rating methodologies or the modification of existing ones. They require the consultation of stakeholders on the new methodologies or the proposed changes and on their justification. New methodologies and their explanation should be published. In addition, CRAs should submit the proposed methodologies to ESMA for the assessment of their compliance with existing requirements. The original proposal had required an approval by ESMA of new methodologies prior to their application by a CRA. ${ }^{71}$ This requirement cannot be found back in the current version of the proposal.

68 Blaurock makes a similar argument in the context of the contractual liability of CRAs vis-à-vis issuers.

69 Art. $35 \mathrm{a}(5)$ of the original proposal.

70 Art. $35 \mathrm{a}(5)$.

71 Art. 22a(3) of the original proposal. 
Under Article 8(7) of the proposal each CRA will be under the obligation to correct errors in its methodologies or in their application, as well as to inform ESMA, the rated entities and generally the public of such errors. CRAs are also required to provide guidance on methodologies and underlying assumptions behind ratings of all asset classes. This guidance should be clear and easily comprehensible. ${ }^{72}$ Under the current Regulation this is only required for structured instruments.

The current Regulation requires that CRAs communicate with the issuer 12 hours in advance of the publication of a rating and the principle grounds on which a rating is based. ${ }^{73}$ Under the proposal, CRAs have to provide to issuers information on the principal grounds on which the rating or an outlook is based during the working hours of the rated entity and at least a full working day before publication. This rule applies to all ratings, whether solicited or not, and to outlooks. Moreover, a decision to discontinue a credit rating has to be disclosed on a non-selective basis and in a timely manner, ${ }^{74}$ whereby the CRA must explain why it chooses to discontinue a credit rating. Additional reporting requirements for CRAs have also been introduced for sovereign ratings, which must in the future be accompanied by a detailed and publicly available research report "explaining all the assumptions, parameters, limits and uncertainties and any other element taken into account in determining that rating or outlook.",75

Next to CRAs also issuers, originators and sponsors of structured finance instruments must disclose to the public, on a webpage run by ESMA, "information on the credit quality and performance of on the individual underlying assets of the structured finance instrument, the structure of the securitization transaction, the cash flows and any collateral supporting a securitization exposure and well informed stress tests on the cash flows and collateral values supporting the underlying exposure. ${ }^{.76}$

\section{Sovereign ratings}

Sovereign credit ratings can be defined as a condensed assessment by CRAs of a government's ability and willingness to repay its public debt both in principal

72 Annex I, Section D, Part 1, point 2a.

73 Annex I, Section D, Part 1, point 3.

74 Art. 10(1).

75 Annex I, Section D, new Part III.

76 Art. 8a. 
and in interests on time. ${ }^{77}$ Generally, CRAs indicate in advance their intention to consider rating changes using negative "review" or "watch" notifications to indicate that a downgrade is likely within the next 90 days. They use a negative "outlook" notification to indicate the potential for a downgrade within the next one or two years. Moody's most frequently precedes its rating changes with credit reviews/watches (27 percent of rating changes are preceded by corresponding credit watches, compared with 14 percent in the case of Standard \& Poor's and only 8 percent in the case of Fitch). ${ }^{78}$

During the recent Euro debt crisis, CRAs were criticised with regard to the quality of their sovereign debt ratings. For instance, according to the President of the European Commission, "ratings appear to be too cyclical, too reliant on the general market mood rather than on fundamentals - regardless of whether market mood is too optimistic or too pessimistic. ${ }^{, 79}$ Some recent research provides some support for this view. In the case of Ireland and Portugal ratings seems to have been changed in the beginning too late compared to macro-economic fundamentals, and then too much once again compared to what justifiable on the basis of macroeconomic variables. ${ }^{80} \mathrm{~A}$ recent IMF study concludes that while markets generally expected downgrades, their extent sometimes surprised them. ${ }^{81}$

Sovereign downgrades have important consequences. First, they generally lead to higher borrowing costs for the government concerned. There is some discussion in the recent academic literature about the relative importance of ratings and outlooks. For instance, Kiff et al. find that most of the incremental information value is transmitted through negative credit warnings (i.e., "outlooks", "reviews" and "watches"), rather than actual rating changes. Yet even though rating changes in general have little market impact, crossing the investment-grade classification boundary leads to higher borrowing costs. ${ }^{82}$ Afonso et al. have observed a significant response of government bond yield spreads to changes in

77 SEC (2011) 1354, 193-194.

78 Kiff et al., op. cit., 11.

79 Barroso, J.M.: Statement to the European Parliament prior to the meeting of the Heads of State and Government of the Euro Area, European Parliament Plenary, Brussels, 5 May 2010.

80 Gärtner M./Griesbach B./Jung F.:., PIGS or Lambs? The European Sovereign Debt Crisis and the Role of rating Agencies, University of St. Gallen, Discussion Paper 2011-06, 2011.

81 Arezki R./Candelon B./Sy, A.: Sovereign rating News and Financial markets Spillovers: Evidence from the European Debt Crisis, IMF Working Paper 11/68, 2011.

82 Kiff et al., op. cit. 
both the rating notations and the rating outlook, particularly important for the case of negative announcements. ${ }^{83}$

What is more, sovereign downgrades are often followed by downgrades of financial institutions as their rating may depend on government's ability to provide financial support. Also the ratings of non-financial institutions may be affected as a sovereign rating serves often as a general benchmark for all other credit ratings for firms located in the country concerned. Often the highest rating possible for most firms in a country is often capped by the country's rating. ${ }^{84}$ Finally, sovereign downgrades may affect the ratings in other countries. Arezki et al. have examined the spillover effects of selected European sovereign rating downgrades during the 2007-2010 period using daily sovereign CDS spreads and stock market indices. ${ }^{85}$ The main result of this study is that sovereign rating downgrades impact not only the financial markets in the country that was downgraded but also other euro area countries. For instance, Austrian CDS spreads and stock market indices moved sharply following the downgrades of Baltic countries, while the Austrian credit rating remained unchanged. One possible explanation for this effect is the exposure of Austrian banks to the Baltic countries.

The proposal does recognise the role of CRAs in sovereign ratings. In the proposed Article 8(5), a new subparagraph is included, requiring CRAs to assess sovereign ratings more frequently: every six months instead of every twelve months. Also additional obligations in relation to the presentation of sovereign ratings are added. As has been highlighted in the previous section, CRAs must publish a detailed research report when issuing and amending sovereign ratings. Sovereign ratings should only be published after the close of business and at least one hour before the opening of trading venues in the European Union. ${ }^{86}$

The current enforced notification period of 12 hours is considered inadequate for sovereigns to verify if the rating event is based on accurate and up-to-date data. This increases the risk of incorrect or out-dated data not being timely removed before the rating process is finalised, which in turn can undermine the quality of the sovereign rating issued. An example of this problem is the downgrade of

83 Afonso A./Furceri, D./Gomes, P.: Sovereign credit ratings and financial markets linkages: Application to European data, in: Journal of International Money and Finance, 31 (2012), 606-638.

84 SEC (2011) 1354, 14.

85 Arezki et al., op. cit.

86 Annex I, Section D, Part III, point 3. 
Greece and Spain by Moody's, three days and one day respectively before the Council meeting on the extension of the EFSF support package by Euro 440 billion on 11 March 2011, when it appeared that the information in the package under negotiation was not completely reflected in the rating process. ${ }^{87}$ Finally, CRAs should disclose the time horizon during which a change of the credit rating is expected in case of a watch procedure.

CRAs are also required to be transparent as to the allocation of staff to the ratings of different asset classes (i.e. corporate, structured finance, sovereign ratings) and they should also provide disaggregated data on their turnover, including data on the fees generated per different asset classes. ${ }^{88}$ This information should allow assessing to what extent CRAs use their resources for the issuance of sovereign ratings.

All these changes will not change the effects of downgrades as discussed above. This is not to say that the proposed changes are useless. As pointed out in the European Commission's Impact Study, the Proposal will 'improve transparency and quality of sovereign debt ratings through verification of underlying information with a sovereign." ${ }^{89}$ CRAs have to verify the accuracy of information with sovereigns to ensure that potential errors of sovereign ratings are avoided. Moreover, transparency will be enhanced through the publication of the full research report accompanying the rating. The publication of sovereign ratings after closure of European trading venues will ensure that new rating information can reach all market participants and thus would limit major market disturbances. The Impact Study also suggested that ESMA, in specific situations, should, under strict conditions and only exceptionally, be allowed to temporarily ban sovereign ratings. ${ }^{90}$ To this end. the proposal foresees that in the case that a CRA does not monitor its sovereign ratings or does not review its sovereign ratings on an ongoing basis and at least every 6 months, ESMA can take the supervisory measures listed in Article 24(1) of Regulation 1060/2009, including the withdrawal of the registration of the credit rating agency, the temporarily prohibition to issuing credit ratings with effect throughout the Union and the suspension of 
the use, for regulatory purposes, of the credit ratings issued by the CRA with effect throughout the Union, until the infringement has been brought to an end. ${ }^{91}$

Finally, the proposal also foresees in a greater role for the European Commission in providing investors with the information necessary to evaluate the creditworthiness of Member States. The preamble to the proposal states in this regard: "Where appropriate and available, and subject to the relevant confidentiality rules applicable in the framework of its surveillance of economic and fiscal policies of Member States, the Commission should complement existing reporting on economic performance of Members States, with possible additional elements or indicators, which may help investors to evaluate the creditworthiness of Member States." 92 In this context the European Commission is also invited to examine "the possibility of developing a European creditworthiness assessment" and, if considered necessary to "submit appropriate legislative proposals." seems that what is effectively suggested here is the establishment of a counterweight to the CRAs sovereign ratings. Yet, regardless of the fact that the European Commission is legally speaking independent from the Member States, it is questionable whether risk assessments issued by an EU institution would be considered credible by the markets.

\section{Conclusions}

The fact that the original Regulation $1060 / 2009$ on CRAs is currently subjected to a second major reform in the space of only a couple of years does not only highlight the rapid developments in the regulatory sphere in times of crisis, but also the care that has been applied in the first place by the European Commission in establishing a regulatory framework for CRAs that would stand the test of time. In retrospect, it is rather astonishing that while the European Commission's reason for regulating CRAs in the EU in the first place was the dubious role that CRAs played in the global financial and economic crisis, the original Regulation $1060 / 2009$ arguably failed to address the main issues, namely the overreliance of investors and regulators on credit ratings, the potential conflict of interests that comes with the CRAs business model, the absence of a civil liability regime and the role of CRAs in rating sovereign debt. What follows from the analysis in this

91 See the proposed inclusion of a new paragraph 46a in Annex III, Part 1.

92 Preamble No. 30a.

93 Ibid. 
contribution is that also the most recent proposal does not remove these issues entirely or even sufficiently.

As initial ideas for the establishment of a quasi-public European credit ratings agency have been abandoned or at least put on hold due to a lack of conviction on the parts of some and a lack of financing on the parts of others, the proposal can only make a modest contribution to enhancing competition through the limitation of contractual relationships, the requirements to get at least two credit ratings and establishment of a European Rating Index. Whether this will really break the dominance of the three big global players in credit ratings remains to be seen.

Probably the single biggest problem of the original Regulation 1060/2009 but also of the current proposal is that of dealing with the overreliance of investors on ratings. Indeed, insides from behavioural science suggest that regulation can have a deteriorating effect on the issue resulting in more rather than less reliance. ${ }^{94}$ The fact that financial institutions would become obliged to make their own credit risk assessment is no guarantee that they will not continue to (implicitly) rely on external credit ratings to make their own assessment. There is a notable silence on parts of the proposal when it comes to suggestions that have been made to analyse and publish the performance of CRAs in a structured manner thereby making use of an independent authority. Transparency of past performance could be an important element in allowing for more competition between CRAs and their rating models.

As the proposal does not suggest abandoning the issuer-pays model, the potential for conflicts of interests continues to persist even if the proposal aims to contain it. What is more, even if the proposal suggests to introduce for the first time the civil liability of CRAs, the latter are unlikely to be much affected by it as it could turn out to be rather difficult for an investor to establish the liability of a CRA in a national court of law.

With regard to sovereign ratings the main novelty of the proposal arguably lies in the enhanced disclosure requirements for CRAs as they do not only have to confirm their information with the sovereign debt issuer but also have to publish the data underlying their rating in a research report that accompanies the rating.

All things considered, the proposal that has resulted from the trilogue can hardly be seen as breaking major ground on any of the issues identified in this contribu- 
tion. In fact, as has been highlighted throughout this contribution, in some areas the political agreement that has resulted from the trilogue between the EP, the Council and the European Commission is actually less far-reaching than the original Commission proposal. This is most notably the case with regard to the limited application of the rotation system for CRAs, the establishment of a European Rating Index and the introduction of a harmonised rating scale. As such, it can only be considered to constitute another stage in the process of establishing an effective regulatory regime for CRAs. 